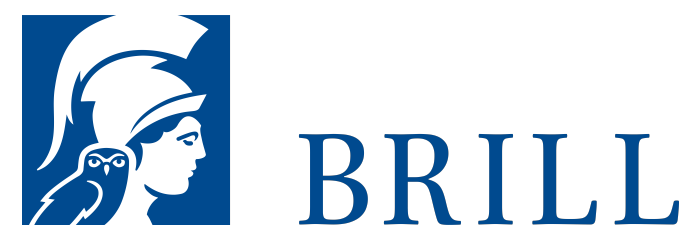

\title{
Der Weg in den Abgrund
}

Deutsche Außenpolitik 1902-1914

Author: Konrad Canis

Nach vorherrschender Auffassung wird Deutschland die Hauptverantwortung für den Ersten Weltkrieg zugeschrieben. Auf breiter Quellengrundlage, vor allem mit ungedruckten Akten- und Nachlassbeständen, begründet jedoch der Autor, dass die Zwänge, denen Deutschland ausgesetzt blieb, größer waren als die Möglichkeiten. Bis zur Julikrise 1914 hat die deutsche Führung mit auf den Frieden gerichteten politischen Mitteln, entweder mit einer Politik der Stärke oder mit einer der Entspannung, auf ei-ne weltmachtpolitische Gleichberechtigung und auf die Sicherung der bisherigen Stellung auf dem europäischen Kontinent gesetzt und versucht, dem Druck der Ausgrenzung durch die Rivalen zu entgehen und die Tripleentente Großbritanniens, Russlands und Frankreichs zu konterkarieren. Unter der sicher- -politischen Zwangsvorstellung, dieser in wenigen Jahren militärisch nicht mehr gewachsen zu sein, hat sie gemeinsam mit Wien im Juli 1914 den Krieg ausgelöst.

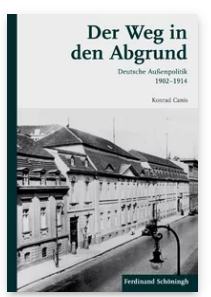

Pages: VI +719

Seiten

Language:

German

Subjects: Early

Modern History, History

Publisher: Brill |

Schöningh

E-Book (PDF)

Released online:

O2 Jan 2012

ISBN: 978-3-

657-77120-2

List price

USD $\$ 138.00$

Hardback

Publication date: 2o Jul 2011

ISBN: 978-3506-77120-9

List price

USD \$138.00 
Konrad Canis, Dr. phil., geb. 1938, bis 2001 Professor an der Humboldt-Universität zu Berlin sowie Gastprofessor an der Universität Wien. Mitglied des Wissenschaftlichen Beirats der Otto-von-Bismarck-Stiftung und Mitherausgeber der Neuen Friedrichsruher Ausgabe der Bismarck-Werke.

For more information see brill.com

Order information: Order online at brill.com +44330333 0049 | customerservices@brill.com Submission information: brill.com/authors

Titles published by Brill | Fink, Brill | mentis or Brill | Schöningh: +49(o)71 5413279216 | brill@brocom.de 